\title{
SYNTHESIS OF NINE SAFROLE DERIVATIVES AND THEIR ANTIPROLIFERATIVE ACTIVITY TOWARDS HUMAN CANCER CELLS.
}

\author{
LUIS ESPINOZA CATALÁN ${ }^{*}$, ALEJANDRO MADRID VILLEGAS ${ }^{1}$, LAUTARO TABORGA LIBER ${ }^{1}$, JOAN \\ VILLENA GARCÍA', MAURICIO CUELLAR FRITIS ${ }^{2}$, AND HÉCTOR CARRASCO ALTAMIRANO.
}

\author{
${ }^{1}$ Departamento de Química, Universidad Técnica Federico Santa María, Av. España $N^{\circ} 1680$, Valparaíso, Chile. \\ ${ }^{2}$ Facultad de Farmacia, Universidad de Valparaíso, Av. Gran Bretaña $N^{\circ} 1093$, Valparaíso, Chile. Centro Regional de Estudios en Alimentos Saludables \\ (CREAS). Centro de Investigaciones y Desarrollo en Alimentos Funcionales (CIDAF). \\ ${ }^{3}$ Departamento de Ciencias Quimicas, Universidad Andrés Bello, Campus Viña del Mar, Los Fresnos $N^{\circ}$ 52, Viña del Mar, Chile. \\ (Received: August 17, 2009 - Accepted: March 25, 2010)
}

\begin{abstract}
Safrole from sassafras oil (Ocotea pretiosa Mez., Lauraceae), is an abundant natural product showing interesting functionality and chemical structure. Starting from safrole, nine derivatives were prepared and assessed for antiproliferative effect using different human cell lines. The in vitro growth inhibition assay was based on the sulphorhodamine dye to quantify cell viability. Some safrole derivatives, (2E)-3-(3',4'-methylenedioxi)phenyl acrylaldehyde (3) and 4-allyl-5nitrobenzene-1,2-diol (4) presented better antiproliferative effect than the parent compound on two breast cancer cell lines (MCF-7 and MDA-MB-231) and one human colorectal cancer cell line (DLD-1) with $\mathrm{IC}_{50}$ values of $55.0 \pm 7.11 \mu \mathrm{M}, 37.5 \pm 2.65 \mu \mathrm{M}$ and $44.0 \pm 6.92 \mu \mathrm{M}$, respectively, without toxicity towards dermal human fibroblast (DHF cells).
\end{abstract}

Keywords: Antiproliferative activity, safrole derivatives, synthesis.

\section{INTRODUCTION}

Cancer is the largest single cause of death in men and women. Recently, resistance to anticancer drugs has been observed. Therefore, the research and development of more effective and less toxic drugs by the pharmaceutical industry has become necessary. Many substances derived from dietary or medicinal plants are known to be effective and versatile chemopreventive and antitumoral agents in a number of experimental models of carcinogenesis. Safrole, from sassafras oil (Ocotea pretiosa Mez., Lauraceae), is an abundant natural product showing interesting functionality and chemical structure. The methylenedioxy unit, present in safrole, can be identified in the clinical antitumour agents etoposide and teniposide ${ }^{1}$ and lignan lactone podophylotoxin ${ }^{2}$.

We have shown what eugenol and this derivates present antioxidant capacity evaluated by the DPPH (1,1-diphenyl-2-picrylhydrazil) and ORAC assays. Eugenol derivatives exhibited a haemolysis percentage lower than $1 \%$, which indicate very low toxicity for red blood cell membranes. ${ }^{3}$ In vitro studies carried out on two human cancer cell lines: DU-145 (androgen-insensitive prostate cancer cells) and KB (oral squamous carcinoma cells) measuring cell viability by the tetrazolium salt assay. Lactic dehydrogenase (LDH) release was also measured to evaluate cell toxicity as a result of cell disruption, subsequent to membrane rupture. In the examined cancer cells, all compounds showed cell-growth inhibition. The results indicate that the compounds 5-allyl3-nitrobenzene-1,2-diol and 4-allyl-2-methoxy-5-nitrophenyl acetate were significantly more active than eugenol $(p<0.001)$, with $\mathrm{IC}_{50}$ values of 19.02 x 10-6 and $21.5 \times 10-6$ mol L-1, respectively, in DU-145 cells and $18.11 \times$ $10-6$ and $21.26 \times 10-6 \mathrm{~mol} \mathrm{L-1}$, respectively, in KB cells, suggesting that the presence of nitro and hydroxyl groups could be important in the activity of these compounds. In addition, our results suggest that apoptosis is induced in $\mathrm{KB}$ and DU-145 cells. In fact, in our experimental conditions, no statistically significant increase in LDH release was observed in cancer cells treated with eugenol and its analogues. ${ }^{4}$ This results suggest that structural analogous of eugenol bearing a nitro group and a hydroxyl group can present antiproliferative/cytotoxic effect on cells.

Antiproliferative screening in vitro provide preliminary data to select compounds with potential antineoplastic properties. Safrole (1) and its synthetic derivatives (2-8) were tested in vitro for antiproliferative effect on two human tumor breast cancer cell lines (MDA-MB-231, MCF-7), one human colorectal cancer cell line (DLD-1) and one dermal human fibroblast cell line (DHF). The in vitro growth inhibition assay used was based on sulphorhodamine dye, widely used to quantify cell viability.

\section{EXPERIMENTAL}

\section{General}

Safrole was obtained commercially from Sigma-Aldrich, and other chemical reagents were purchased (Merck or Aldrich) with the highest purity commercially available and were used without previous purification. IR spectra were obtained by using $\mathrm{KBr}$ pellets or thin films in a Nicolet Impact 420 spectrometer. Frequencies are reported in $\mathrm{cm}^{-1}$. Low resolution mass spectra were recorded on a Shimadzu QP-2000 spectrometer at $70 \mathrm{eV}$ ionising voltage and are given as $\mathrm{m} / \mathrm{z}$ (\% rel. int.) ${ }^{1} \mathrm{H},{ }^{13} \mathrm{C}$ (DEPT 135 and DEPT 90). Some spectra were recorded in $\mathrm{CDCl}_{3}$ solutions and were referenced to the residual peaks of $\mathrm{CHCl}_{3}, \mathrm{~d}=7.26 \mathrm{ppm}$ and $\mathrm{d}=77.0 \mathrm{ppm}$ for ${ }^{1} \mathrm{H}$ and ${ }^{13} \mathrm{C}$, respectively; $\mathrm{CD}_{3} \mathrm{COCD}_{3}$ solutions were referenced to the residual peaks of $\mathrm{CH}_{3} \mathrm{COCH}_{3}$, $\mathrm{d}=2.04 \mathrm{ppm}$ and $\mathrm{d}=29.8 \mathrm{ppm}$ for ${ }^{1} \mathrm{H}$ and ${ }^{13} \mathrm{C}$, respectively, on a Bruker Avance 400 Digital NMR spectrometer operating at $400.1 \mathrm{MHz}$ for ${ }^{1} \mathrm{H}$ and $100.6 \mathrm{MHz}$ for ${ }^{13} \mathrm{C}$. Chemical shifts are reported in $\mathrm{d} \mathrm{ppm}$ and coupling constants $(\mathrm{J})$ are given in Hz. Silica gel (Merck 200-300 mesh) was used for C.C. and silica gel plates HF-254 for TLC. TLC spots were detected by heating after spraying with $25 \% \mathrm{H}_{2} \mathrm{SO}_{4}$ in $\mathrm{H}_{2} \mathrm{O}$.

\section{Synthesis}

4-allyl-5-nitro-1,2-methylenedioxibenzene (2) and (2E)-3-(3',4'methylenedioxi)phenyl acrylaldehyde (3)

To a solution of safrole 1 in acetic acid $(8 \mathrm{~mL})$ at $-5^{\circ} \mathrm{C}(2.0 \mathrm{~g}, 12.3 \mathrm{mmol})$ a solution of nitric acid and sulphuric acid at $-5^{\circ} \mathrm{C}(10: 1$ ratio; $2.5 \mathrm{~mL})$ was added dropwise. The mixture at $-10^{\circ} \mathrm{C}$ was stirred for $4 \mathrm{~h}$, taken up in water $(10 \mathrm{~mL})$ and extracted with ethyl acetate (EtOAc, $3 \times 50 \mathrm{~mL}$ ). The organic layer was washed to neutrality with a saturated $\mathrm{NaHCO}_{3}$ solution, dried over $\mathrm{MgSO}_{4}$ and taken to dryness under reduced pressure. The residue was chromatographed on a silica gel column with mixtures of petroleum ether (PE)/EtOAc of increasing polarity $(19.8: 0.2 \rightarrow 17.8: 2.2)$. After TLC comparison, $1.86 \mathrm{~g}(75.0 \%)$ of compound 2 and $0.11 \mathrm{~g}(5.2 \%)$ of compound 3 were obtained. Compound $\underline{\mathbf{2}}$, red viscous oil; IR $\left(\mathrm{cm}^{-1}\right)$ : $3081(=\mathrm{C}-\mathrm{H}) ; 2912(\mathrm{C}-\mathrm{H}) ; 1616(\mathrm{C}=\mathrm{C}) ; 1523$ $\left(-\mathrm{NO}_{2}\right) ; 1480(\mathrm{C}=\mathrm{C}) ; 1421\left(-\mathrm{CH}_{2}\right) ; 1328(\mathrm{~N}=\mathrm{O}) ; 1257$ (C-O-C); 927 (-C-O-C-); 817 (-C-H). M.S. (m/z, \%):208 (2.8); 207 (23.0); 190 (100); 177 (21.0); 176 (17.5); 173 (50.2); 162 (16.9); 160 (23.0); 132 (29.7); 103 (24.9); 102 (51.3); 77 (43.9); 76 (22.6); 53 (16.2); 51 (19.4). ${ }^{1}$ H NMR: 7.49 (s, 1H, H-6); 6.76 (s, $1 \mathrm{H}, \mathrm{H}-3) ; 6.09\left(\mathrm{~s}, 2 \mathrm{H}, \mathrm{OCH}_{2} \mathrm{O}\right) ; 5.95(\mathrm{ddt}, 1 \mathrm{H}, 1 \mathrm{H}, \mathrm{J}=17.0,10.3$ and $6.5 \mathrm{~Hz}$, H-2'); 5.10 (m, 2H, H-3'); 3.65 (d, 2H, J=4.0 Hz, H-1'); ${ }^{13}$ C NMR: 151.7 (s, C-2); 146.5 (s, C-5 and s, C-1); 135.2 (d, C-2'); 132.2 (s, C-4); 117.0 (t, C-3'); 110.4 (d, C-3); 105.7 (t, $\left.\mathrm{OCH}_{2} \mathrm{O}\right) ; 102.7$ (d, C-6); 37.6 (t, C-1');

Compound $\underline{\mathbf{3}}$, yellow viscous oil; IR $\left(\mathrm{cm}^{-1}\right): 2913(\mathrm{C}-\mathrm{H}) ; 2825(\mathrm{C}-\mathrm{H})$; 
$1724(\mathrm{C}=\mathrm{O}) ; 1663(\mathrm{C}=\mathrm{C}-\mathrm{C}=\mathrm{O}) ; 1610(\mathrm{C}=\mathrm{C}) ; 1492(\mathrm{C}=\mathrm{C}) ; 1254(\mathrm{C}-\mathrm{O}-\mathrm{C}) ; 938$ (-C-O-C-). ${ }^{1}$ H NMR: 9.65 (d, 1H, J=7.7 Hz, H-3'); 7.38 (d, 1H, J=15.8 Hz, H-1'); 7.08 (dd, 2H, J=1.7 and $\mathrm{J}=8.6 \mathrm{~Hz}, \mathrm{H}-5) ; 7.06(\mathrm{~d}, 1 \mathrm{H}, \mathrm{J}=1.7 \mathrm{~Hz}, \mathrm{H}-3)$; $6.86(\mathrm{~d}, 1 \mathrm{H}, \mathrm{J}=8.6 \mathrm{~Hz}, \mathrm{H}-6) ; 6.56\left(\mathrm{dd}, 1 \mathrm{H}, \mathrm{J}=7.7 \mathrm{~Hz}\right.$ and $\left.\mathrm{J}=15.8 \mathrm{~Hz}, \mathrm{H}-2^{\prime}\right), 6.04$ (s, 2H, $\mathrm{OCH}_{2} \mathrm{O}$ ); ${ }^{13} \mathrm{C}$ NMR: 193.9 (d, CHO); 152.9 (d, C-1'); 150.1 (s, C-1); 148.5 (s, C-2); 128.3 (s, C-4); 127.0 (d, C-2'); 124.7 (d, C-5); 107.7 (d, C-3); $107.3(\mathrm{~d}, \mathrm{C}-6) ; 101.0\left(\mathrm{t}, \mathrm{OCH}_{2} \mathrm{O}\right)$

\section{4-allyl-5-nitrobenzene-1,2-diol (4)}

To a cold suspension of $\mathrm{AlCl}_{3}(0.68 \mathrm{~g}, 5.1 \mathrm{mmol})$ in $\mathrm{CH}_{2} \mathrm{Cl}_{2}(5.0 \mathrm{~mL})$ at $0{ }^{\circ} \mathrm{C}$ (under $\mathrm{N}_{2}$ atmosphere) a solution at $-5{ }^{\circ} \mathrm{C}$ of $2(0.30 \mathrm{~g}, 1.5 \mathrm{mmol})$ in $\mathrm{CH}_{2} \mathrm{Cl}_{2}(7.0 \mathrm{~mL})$ was slowly added. The resulting mixture was stirred for $2 \mathrm{~h}$ at $-10{ }^{\circ} \mathrm{C}$. Cold water was added to the mixture (approx. $10 \mathrm{~mL}$ ). The resulting mixture was stirred for $18 \mathrm{~h}$ at room temperature under nitrogen. The reaction mixture was poured into brine solution and extracted with EtOAc $(3 \times 100$ $\mathrm{mL}$ ). The organic layer was washed with brine then dried over $\mathrm{MgSO}_{4}$, filtered evaporated and re-dissolved in $5 \mathrm{~mL}$ of acetone. After that, it was adsorbed on silica, chromatographed by $\mathrm{CC}$ eluting with mixtures of petroleum ether/ EtOAc of increasing polarity $(17.0: 3.0 \rightarrow 15.0: 5.0)$ to give 4 , an orange oil $(0.16$ g, 57.4\% ). IR $\left(\mathrm{cm}^{-1}\right): 3311(\mathrm{O}-\mathrm{H}) ; 2907(\mathrm{C}-\mathrm{H}) ; 1598(\mathrm{C}=\mathrm{C}) ; 1526\left(\mathrm{NO}_{2}\right) ; 1495$ $(\mathrm{C}=\mathrm{C}) ; 1429\left(-\mathrm{CH}_{2}\right) ; 1326(\mathrm{~N}=\mathrm{O}) ; 1275(\mathrm{C}-\mathrm{O}) ; 1045(-\mathrm{C}-\mathrm{OH}) ; 809(-\mathrm{C}-\mathrm{H})$. 'H NMR: 8.99 (bs, 2H, OH); 7.57 (s, 1H, H-6); 6.84 (s, 1H, H-3); 5.95 (ddt, $1 \mathrm{H}, 1 \mathrm{H}, \mathrm{J}=17.0,10.3$ and $\left.6.5 \mathrm{~Hz}, \mathrm{H}-2^{\prime}, \mathrm{H}-2^{\prime}\right) ; 5.03$ (m, 2H, H-3'); 3.61 (d, $2 \mathrm{H}, \mathrm{J}=6.4 \mathrm{~Hz}, \mathrm{H}-1$ '); ${ }^{13} \mathrm{C}$ NMR: 151.3 (s, C-2); 144.4 (s, C-1); 141.4 (d, C-5); 137.1 (d, C-2'); 129.7 (s, C-4); 118.4 (t, C-3'); 116.3 (d, C-3); 113.0 (d, C-6); $37.6\left(\mathrm{t}, \mathrm{C}-1^{\prime}\right)$.

3-(3',4'-methylenedioxi)phenyl 1-(3',4'-methylenedioxi)phenyl propan-2-ol (6)

The compound $1(1.0 \mathrm{~g}, 6.2 \mathrm{mmol})$ to $-5^{\circ} \mathrm{C}$, under $\mathrm{N}_{2}$ atmosphere was slowly hydroborated with a $2.0 \mathrm{M}$ solution of $\mathrm{BH}_{3} \cdot \mathrm{DMS} / \mathrm{THF}(0.67 \mathrm{~mL})$ at $-10{ }^{\circ} \mathrm{C}$ for $15 \mathrm{~min}$ was added dropwise. Then the mixture was stirred at room temperature for $1 \mathrm{~h}$. The resulting organoborane is oxidized with sodium perborate $(0.95 \mathrm{~g}, 6.2 \mathrm{mmol})$ and water $(100 \mathrm{~mL})$. The mixture was stirred at room temperature for $2 \mathrm{~h}$. Then, it was extracted with portions of ethyl ether $(4 \times 50 \mathrm{~mL})$ and the layers were separated. The organic layer was dried over $\mathrm{MgSO}_{4}$, filtered, evaporated and re-dissolved in $5 \mathrm{~mL}$ of $\mathrm{CH}_{2} \mathrm{Cl}_{2}$. It was adsorbed on silica, chromatographed by $\mathrm{CC}$ eluting with mixtures of petroleum ether/EtOAc of increasing polarity $(18.8: 1.2 \rightarrow 17.6: 2.4)$. Then two fractions were obtained: fraction I $(0.66 \mathrm{~g}(59.4 \%)$ of compound $\mathbf{5})$ and fraction II (12 $\mathrm{mg}(1.1 \%)$ of isomer compound $\mathbf{6})$. Compound $\underline{\mathbf{5}}$, yellow viscous oil; IR $(\mathrm{cm}$ 1): $3330(\mathrm{O}-\mathrm{H}) ; 2909(\mathrm{C}-\mathrm{H}) ; 1495(\mathrm{C}=\mathrm{C}) ; 1439\left(-\mathrm{CH}_{2}\right) ; 1245(\mathrm{C}-\mathrm{O}-\mathrm{C}) ; 1039$ (-C-OH); 932 (C-O-C); 811 (-C-H). M.S. (m/z, \%): 181 (6.2); 180 (51.6); 136 (51.2); 135 (100); 119 (5.4); 106 (9.5); 105 (7.8); 104 (5.1); 91 (10.5); 78 (7.1); 77 (19.7); 65 (7.3); 51 (8.6). 'H NMR: 6.73 (d, 1H, J=7.6 Hz, H-6); 6.69 $(\mathrm{d}, 1 \mathrm{H}, \mathrm{J}=1.4 \mathrm{~Hz}, \mathrm{H}-3) ; 6.64(\mathrm{dd}, 1 \mathrm{H}, \mathrm{J}=1.4$ and $\mathrm{J}=7.6 \mathrm{~Hz}, \mathrm{H}-5) ; 5.91(\mathrm{~s}, 2 \mathrm{H}$, $\mathrm{OCH}_{2} \mathrm{O}$ ); 3.65 (t, 2H, J=6.4 Hz, H-3'); 2.62 (t, 2H, J=7.4 Hz, H-1'); 1.84 $\left(\mathrm{dt}, 2 \mathrm{H}, \mathrm{J}=6.4\right.$ and $\left.\mathrm{J}=15.2 \mathrm{~Hz}, \mathrm{H}-2^{\prime}\right) ; 1.56(\mathrm{bs}, 1 \mathrm{H}, \mathrm{OH}) ;{ }^{13} \mathbf{C}$ NMR: $147.5(\mathrm{~s}$, C-2); 145.6 (s, C-1); 135.6 (s, C-4); 121.1 (d, C-5); 108.8 (d, C-6); 108.1 (d, $\mathrm{C}-3) ; 100.7\left(\mathrm{t}, \mathrm{OCH}_{2} \mathrm{O}\right) ; 62.1$ (t, C-3'); $34.4\left(\mathrm{t}, \mathrm{C}-1^{\prime}\right) ; 31.7$ (t, C-2'). Compound 6. yellow viscous oil; IR $\left(\mathrm{cm}^{-1}\right)$ : $3411(\mathrm{O}-\mathrm{H}) ; 2910(\mathrm{C}-\mathrm{H}) ; 1495(\mathrm{C}=\mathrm{C}) ; 1439$ $\left(-\mathrm{CH}_{2}\right) ; 1367\left(\mathrm{CH}_{3}\right) ; 1245(\mathrm{C}-\mathrm{O}-\mathrm{C}) ; 1036$ (-C-OH); 935 (C-O-C); 803 (-CH). ${ }^{1} \mathbf{H}$ NMR: $6.77(\mathrm{~d}, 1 \mathrm{H}, \mathrm{J}=7.8 \mathrm{~Hz}, \mathrm{H}-6) ; 6.71(\mathrm{~d}, 1 \mathrm{H}, \mathrm{J}=1.5 \mathrm{~Hz}, \mathrm{H}-3) ; 6.65$ (dd, $1 \mathrm{H}, \mathrm{J}=1.5$ and $\mathrm{J}=7.8 \mathrm{~Hz}, \mathrm{H}-5) ; 5.93\left(\mathrm{~s}, 2 \mathrm{H}, \mathrm{OCH}_{2} \mathrm{O}\right) ; 3.96$ (m, 1H, H-2'); $2.71(\mathrm{dd}, 1 \mathrm{H}, \mathrm{J}=4.7$ and $\mathrm{J}=13.6 \mathrm{~Hz}, \mathrm{H}-1$ ' $) 2.59(\mathrm{dd}, 2 \mathrm{H}, \mathrm{J}=8.1$ and $\mathrm{J}=13.6 \mathrm{~Hz}$, $\mathrm{H}-1^{\prime}$ ); 1.6 (bs, $\left.1 \mathrm{H}, \mathrm{OH}\right) ; 1.23$ (d, 3H, J=6.2 Hz, H-3'); ${ }^{13}$ C NMR: 147.8 (s, C-2); 146.2 (s, C-1); 132.2 (s, C-4); 122.3 (d, C-5); 109.7 (d, C-6); 108.3 (d, C-3); 100.9 (t, $\left.\mathrm{OCH}_{2} \mathrm{O}\right) ; 68.9$ (d, C-2'); 45.4 (t, C-1'), 22.7 (c, C-3').

3-(3',4'-methylenedioxi-6'-nitro)phenyl propan-1-ol (7) and 1-(3',4'-methylenedioxi-6-nitro)phenyl propan-2-ol (8)

Some $0.30 \mathrm{~g}(1.5 \mathrm{mmol})$ of compound 2 at $-5^{\circ} \mathrm{C}$ under $\mathrm{N}_{2}$ atmosphere was hydroborated with a $2.0 \mathrm{M}$ solution of $\mathrm{BH}_{3} \cdot \mathrm{DMS} / \mathrm{THF}(0.27 \mathrm{~mL})$ at $-10^{\circ} \mathrm{C}$ for $15 \mathrm{~min}$. The reagent was added dropwise and the mixture was stirred at room temperature for $1 \mathrm{~h}$. The resultant organoborane was oxidized with sodium perborate solution $(0.28 \mathrm{~g}, 1.5 \mathrm{mmol})$ in water $(100 \mathrm{~mL})$. The mixture was stirred at room temperature for $2 \mathrm{~h}$ and then extracted with ethyl ether $\left(\mathrm{Et}_{2} \mathrm{O}\right.$, $4 \times 50 \mathrm{~mL}$ ). The organic layer was dried over $\mathrm{MgSO}_{4}$, filtered and taken to dryness. The residue was adsorbed on silica gel and chromatographed by $\mathrm{CC}$ eluting with mixtures of $\mathrm{PE} / \mathrm{EtOAc}$ of increasing polarity (16.0:4.0 $\rightarrow 14.0: 6.0)$. Two fractions were obtained: $0.17 \mathrm{~g}(53.1 \%)$ of compound 7 and $7.8 \mathrm{mg}$ (2.4\%) of compound 8. Compound $\mathbf{7}$, dark yellow solid, $\mathrm{mp}\left(85.9-87.9^{\circ} \mathrm{C}\right)$; IR $\left(\mathrm{cm}^{-1}\right): 3211(\mathrm{O}-\mathrm{H}) ; 2907(\mathrm{C}-\mathrm{H}) ; 1613(\mathrm{C}=\mathrm{C}) ; 1521\left(\mathrm{NO}_{2}\right) ; 1419\left(-\mathrm{CH}_{2}\right) ; 1337$
$(\mathrm{N}=\mathrm{O}) ; 1260$ (C-O-C); 1045 (-C-OH); 922 (C-O-C); 825 (-C-H). ${ }^{1}$ H NMR: $7.46(\mathrm{~s}, 1 \mathrm{H}, \mathrm{H}-6) ; 6.76(\mathrm{~s}, 1 \mathrm{H}, \mathrm{H}-3) ; 6.08\left(\mathrm{~s}, 2 \mathrm{H}, \mathrm{OCH}_{2} \mathrm{O}\right) ; 3.71(\mathrm{t}, 2 \mathrm{H}, \mathrm{J}=6.2$ $\left.\mathrm{Hz}, \mathrm{H}-3^{\prime}\right) ; 2.96\left(\mathrm{dd}, 2 \mathrm{H}, \mathrm{J}=6.4\right.$ and $\left.\mathbf{J}=8.6 \mathrm{~Hz}, \mathrm{H}-1^{\prime}\right) ; 1.90$ (m, 2H, H-2') 1.50 (bs, 1H, OH); ${ }^{13}$ C NMR: 151.7 (s, C-2); 146.3 (s, C-1); 142.8 (s, C-5); 134.4 (s, C-4); 110.6 (d, C-3); 105.7 (d, C-6); 102.7 (t, $\left.\mathrm{OCH}_{2} \mathrm{O}\right) ; 62.0$ (t, C-3'); 33.4 (t, C-2'); 30.1 (t, C-1'). Compound $\underline{\mathbf{8}}$, dark yellow solid, mp $\left(92.6-94.1{ }^{\circ} \mathrm{C}\right)$; IR $\left(\mathrm{cm}^{-1}\right)$ : $3241(\mathrm{O}-\mathrm{H}) ; 2921(\mathrm{C}-\mathrm{H}) ; 1620(\mathrm{C}=\mathrm{C}) ; 1515\left(\mathrm{NO}_{2}\right) ; 1481\left(-\mathrm{CH}_{2}\right)$; $1378\left(-\mathrm{CH}_{3}\right) ; 1325(\mathrm{~N}=\mathrm{O}) ; 1258$ (C-O-C); 1031 (-C-OH); 921 (C-O-C); 866 (-C-H). ${ }^{1}$ H NMR: 7.50 (s, 1H, H-6); 6.80 (s, 1H, H-3); 6.09 (d, 2H, J=0.6 Hz, $\left.\mathrm{OCH}_{2} \mathrm{O}\right) ; 4.11\left(\mathrm{~m}, 1 \mathrm{H}, \mathrm{H}-2^{\prime}\right) ; 3.14\left(\mathrm{dd}, 1 \mathrm{H}, \mathrm{J}=3.9\right.$ and $\left.\mathrm{J}=13.5 \mathrm{~Hz}, \mathrm{H}-{ }^{\prime}{ }^{\prime}\right) ; 2.88$ (dd, $1 \mathrm{H}, \mathrm{J}=8.3$ and $\left.\mathrm{J}=13.5 \mathrm{~Hz}, \mathrm{H}-{ }^{\prime}{ }_{\mathrm{b}}\right) ; 1.59$ (bs, $\left.1 \mathrm{H}, \mathrm{OH}\right) ; 1.31$ (d, $3 \mathrm{H}, \mathrm{J}=6.2$ Hz, H-3'); ${ }^{13}$ C NMR: 151.5 (s, C-2); 146,7 (s, C-5 and s, C-1); 131.2 (s, C-4); 111.6 (d, C-3); 105.7 (t, OCH $\mathrm{O}$ ); 102.8 (d, C-6); 68.4 (d, C-2'); 42,9 (t, C-1'), $23.7\left(\mathrm{c}, \mathrm{C}-3^{\prime}\right)$.

\section{4-allyl-5-nitro-1,2-phenylene diacetate (9)}

To a solution of $4(0.38 \mathrm{~g}, 1.92 \mathrm{mmol})$ in dry $\mathrm{CH}_{2} \mathrm{Cl}_{2}(60 \mathrm{~mL})$, DMAP $(3.75 \mathrm{mg})$ and $\mathrm{Ac}_{2} \mathrm{O}(0.36 \mathrm{~mL}, 3.84 \mathrm{mmol})$ were added and the mixture was stirred at room temperature for $2 \mathrm{~h}$. A cooled solution of $10 \% \mathrm{KHSO}_{4}$ (approx. $50 \mathrm{~mL}$ ) was then added to this mixture. The watery layer was discarded and the organic layer was washed to neutrality with a saturated solution of $\mathrm{NaHCO}_{3}$ and water. Then it was dried over $\mathrm{MgSO}_{4}$, filtered, evaporated and re-dissolved in $5 \mathrm{~mL}$ of $\mathrm{CH}_{2} \mathrm{Cl}_{2}$. Subsequently, it was adsorbed on silica and chromatographed by $\mathrm{CC}$ with petroleum ether/EtOAc mixtures of increasing polarity (19.8:0.2 $\rightarrow 16.4: 3.6)$ to give $9,(0.50 \mathrm{mg}, 94.3 \%)$, a dark yellow solid, $\mathrm{mp}\left(62.0-63.7^{\circ} \mathrm{C}\right)$; IR $\left(\mathrm{cm}^{-1}\right): 3083(=\mathrm{C}-\mathrm{H}) ; 2938(\mathrm{C}-\mathrm{H}) ; 1779(\mathrm{C}=\mathrm{O}) ; 1639$ $(\mathrm{C}=\mathrm{C}) ; 1527(\mathrm{C}=\mathrm{C}) ; 1370\left(\mathrm{CH}_{3}\right) ; 1272(\mathrm{C}-\mathrm{O}-\mathrm{C})$. M.S. (m/z, \%): 237 (18.4); 220 (25.2); 195 (48.1); 179 (12.9); 178 (100); 165 (40.1); 164 (21.8); 161 (25.0); 149 (11.3); 147 (13.3); 91 (9.5); 65 (10.4). ${ }^{1}$ H NMR: 7.87 (s, 1H, H-6); $7.21(\mathrm{~s}, 1 \mathrm{H}, \mathrm{H}-3) ; 5.92\left(\mathrm{ddt}, 1 \mathrm{H}, \mathrm{J}=17.1,10.2\right.$ and $\left.6.6 \mathrm{~Hz}, \mathrm{H}-2^{\prime}\right) ; 5.12(\mathrm{~m}, 2 \mathrm{H}$, H-3'); 3.67 (d, 2H, J=6.6 Hz, H-1'); 2.30 (s, 6H, CH $).{ }^{13} \mathbf{C}$ RMN: 167.4 (s, $\left.2 \mathrm{xCH}_{3} \mathrm{CO}\right) ; 145.7$ (s, C-5); 145.5 (s, C-2); 140.3 (s, C-1); 134.2 (t, C-2'); 134.0 (s, C-4); 126.2 (d, C-3); 120.6 (t, C-3'); 117.9 (d, C-6); 36.5 (t, C-1'); 20.4 (c, $\left.2 \mathrm{x}^{-} \mathrm{H}_{3} \mathrm{CO}\right)$.

\section{3-( 3',4'-methylenedioxi-6-nitro)phenylpropyl acetate (10)}

To a solution of $7(97.8 \mathrm{mg}, 0.43 \mathrm{mmol})$ in dry $\mathrm{CH}_{2} \mathrm{Cl}_{2}(30 \mathrm{~mL})$, DMAP $(0.98 \mathrm{mg})$ and $\mathrm{Ac}_{2} \mathrm{O}(40.7 \mu \mathrm{L}, 0.43 \mathrm{mmol})$ were added and the mixture was stirred at room temperature for $2 \mathrm{~h}$. A cooled solution of $10 \% \mathrm{KHSO}_{4}(50 \mathrm{~mL}$ approx) was then added to this mixture. The watery layer was discarded and the organic layer was washed to neutrality with a saturated solution of $\mathrm{NaHCO}_{3}$ and water. It was dried over $\mathrm{MgSO}_{4}$, filtered, evaporated and re-dissolved in 5 $\mathrm{mL}$ of $\mathrm{CH}_{2} \mathrm{Cl}_{2}$ and adsorbed on silica, chromatographed by $\mathrm{CC}$ and eluting with petroleum ether/EtOAc mixtures of increasing polarity $(19.8: 0.2 \rightarrow 19.0: 1.0)$ to give 10, an dark yellow oil $(110.4 \mathrm{mg}, 95.1 \%)$. IR $\left(\mathrm{cm}^{-1}\right)$ : $2778(\mathrm{C}-\mathrm{H}) ; 1735$ $(\mathrm{C}=\mathrm{O}) ; 1619(\mathrm{C}=\mathrm{C}) ; 1516\left(\mathrm{NO}_{2}\right) ; 1425\left(-\mathrm{CH}_{2}\right) ; 1379\left(\mathrm{CH}_{3}\right) ; 1330(\mathrm{~N}=\mathrm{O}) ; 1260$ (C-O-C); 1255 (C-O-C); 928 (C-O-C); 817 (-C-H). M.S. (m/z, \%): 208 (16.0); 191 (13.6); 190 (100); 189 (14.5); 178 (23.1); 173 (9.2); 163 (19.9); 148 (13.7); 136 (13.3); 135 (13.1); 132 (15.7); 104 (9.9); 77 (12.2). ${ }^{1}$ H NMR: 7.43 (s, 1H, H-6); 6.69 (s, 1H, H-3); 6.05 (s, 2H, OCH $\mathrm{O}) ; 4.07$ (t, 2H, J=6.3 Hz, H-3'); 2.89 (m, 2H, H-1'); 2.03 (s, 3H, $\left.\mathrm{CH}_{3}\right) ; 1.93$ (m, 2H, H-2'). ${ }^{13} \mathrm{C}$ NMR: 170.4 (s, $\mathrm{CH}_{3} \mathrm{CO}$ ); 151.6 (s, C-2); 146.3 (s, C-1); 142.6 (s, C-5); 133.5 (s, C-4); 110.6 (d, C-3); 105.6 (t, $\left.\mathrm{OCH}_{2} \mathrm{O}\right) ; 102.7$ (d, C-6); 63.4 (t, C-3'); 30.5 (t, C-2'); 29.3 (t, $\left.\mathrm{C}-1^{\prime}\right) ; 20.8\left(\mathrm{c}, \mathrm{CH}_{3} \mathrm{CO}\right)$.

\section{Cell Culture}

The cell cultures used were obtained from American Type Culture Collection (Rockville, MD, USA). Breast cancer cell lines (MDA-MB-231, MCF-7), a colorectal cancer cell line (DLD-1) and human dermal fibroblast (DHF) were grown in DMEM-F12 medium containing 10\% fetal calf serum (FCS), $100 \mathrm{IU} / \mathrm{mL}$ penicillin, $100 \mu \mathrm{g} / \mathrm{mL}$ streptomycin and $1 \mathrm{mM} \mathrm{L}$-glutamine. Cells were seeded into 96 well microtiter plates in $100 \mu \mathrm{L}$ at plating density of $3 \times 10^{3}$ cells/well. After $24 \mathrm{~h}$ incubation at $37^{\circ} \mathrm{C}$ (under a humidified $5 \%$ carbon dioxide atmosphere to allow cell attachment) the cells were treated with different concentrations of safrole and derivatives $(0-100 \mu \mathrm{M})$ and daunorubicin $(0.05$ $50 \mu \mathrm{M})$ and incubated for $72 \mathrm{~h}$ under the same conditions. Stock solutions of compounds were prepared in ethanol and the final concentration of this solvent was kept constant at $1 \%$. Control cultures received $1 \%$ ethanol alone.

Cell viability was determined by the sulforhodamine B assay according to Skehan et al. $1990^{5}$ with some modifications ${ }^{6}$. Briefly, at the end of drug exposure, cells were fixed with $50 \%$ trichloroacetic acid at $4^{\circ} \mathrm{C}$ (TCA final concentration $10 \%$ ). After washing with destilled water, cells were stained with $0.1 \%$ sulforhodamine B (Sigma-Aldrich, St. Louis, MO), dissolved in 
$1 \%$ acetic acid $(50 \mu \mathrm{L} /$ well $)$ for $30 \mathrm{~min}$, and subsequently washed with $1 \%$ acetic acid to remove unbound stain. Protein-bound stain was solubilized with $100 \mu \mathrm{L}$ of $10 \mathrm{mM}$ unbuffered Tris base. The cell density was determined using a fluorescence plate reader (wavelength 540nm). Values shown, are the mean + $\mathrm{SD}$ of three independent experiments in triplicate.

\section{RESULTS AND DISCUSSION}

Synthesis Nitrosafrol (2) obtained under standard conditions ${ }^{7-10}\left(\mathrm{HNO}_{3} /\right.$ $\mathrm{H}_{2} \mathrm{SO}_{4} / \mathrm{HAc}$ ) afforded the nitro compound 2 and aldehyde 3 with $75.0 \%$ and $5.2 \%$ yields respectively (scheme 1). Oxidative hydroboration of the side chain of nitrosafrol led to an alcohol at C-3'. Nitrosafrol was oxidized using $\mathrm{BH} \cdot \mathrm{DMS} / \mathrm{THF} / \mathrm{NaBO}_{3} \cdot 4 \mathrm{H}_{2} \mathrm{O} / \mathrm{H}_{2} \mathrm{O}$ as previously described for other alkenes and alkynes ${ }^{11}$. The primary alcohol 7 was obtained with a $53.1 \% \mathrm{w} / \mathrm{w}$ yield and the secondary alcohol 8 with $2.4 \%$ yield (scheme 1 ).

All the compounds were characterized mainly by NMR, IR and MS spectral data. In the ${ }^{1} \mathrm{H}$ NMR spectrum of nitrosafrol 2 , two signals at $\mathrm{d}=7.49$ $(\mathrm{s}, 1 \mathrm{H}) ; 6.76(\mathrm{~s}, 1 \mathrm{H})$ were assigned to $\mathrm{H}-6$ and $\mathrm{H}-3$ respectively. In the ${ }^{13} \mathrm{C}$ NMR spectrum the signals of $\mathrm{C}-5$ and $\mathrm{C}-1$ were observed at $\mathrm{d}=146.5 \mathrm{ppm}$ for a pair of overlapping quaternary carbons which corresponds to a C-5 linked to the nitro group.

In the IR spectrum of compound 3, the absorption at $1724 \mathrm{~cm}^{-1}$ was assigned to an aldehyde carbonyl group, whereas in the ${ }^{1} \mathrm{H}$ NMR spectrum the signal at $\mathrm{d}=9.65(\mathrm{~d}, 1 \mathrm{H}, \mathrm{J}=7.7 \mathrm{~Hz})$ was assigned to an aldehyde associated to the signals at $\mathrm{d}=7.38(\mathrm{~d}, 1 \mathrm{H}, \mathrm{J}=15.8 \mathrm{~Hz})$ and $6.56(\mathrm{dd}, 1 \mathrm{H}, \mathrm{J}=7.7 \mathrm{~Hz}$ and $\mathrm{J}=15.8$ $\mathrm{Hz}$ ) corresponding to an $\alpha, \beta$ unsaturated system ( $\mathrm{H}-\mathrm{2}^{\prime}$ ' and $\left.\mathrm{H}-\mathrm{1}^{\prime}\right)$. Cleavage of the methylenedioxy ring of nitrosafrol took place during the conversion into the catechol 4 (57.4\% yield) using the $\mathrm{AlCl}_{3} / \mathrm{CH}_{2} \mathrm{Cl}_{2} / \mathrm{H}_{2} \mathrm{O}$ method ${ }^{12-15}$. In the ${ }^{1} \mathrm{H}$ NMR spectrum, the absence of the methylenedioxy singlet between 5.90$6.05 \mathrm{ppm}$ confirmed the presence of catechol coupled with a broad signal at $\mathrm{d}=8.99$ (brs, 2H). The MS spectrum from the diacetate derivative 9 showed two peaks at $\mathrm{m} / \mathrm{z} 220(25.2 \%)$ and $161(25.0 \%)$ attributed to the loss of two acetate groups.

Oxidative hydroboration of the side chain in safrole $\mathbf{1}$ was carried out to obtain the alcohol at C-3' using the $\mathrm{BH}_{3} \cdot \mathrm{DMS} / \mathrm{THF} / \mathrm{NaBO}_{3} \cdot 4 \mathrm{H}_{2} \mathrm{O} / \mathrm{H}_{2} \mathrm{O}$ method. As in the previous oxidation, the primary alcohol 5 was obtained with a $59.4 \%$ and the secondary alcohol 6 with $1.1 \% \mathrm{w} / \mathrm{w}$ yield ${ }^{11,16-18}$ (scheme 1$)$. In the ${ }^{1} \mathrm{H}$ NMR spectrum of compound $\mathbf{5}$, three signals at $\mathrm{d}=3.65(\mathrm{t}, 2 \mathrm{H}, \mathrm{J}=6.4$ $\mathrm{Hz}) ; 2.62(\mathrm{t}, 2 \mathrm{H}, \mathrm{J}=7.4 \mathrm{~Hz})$ and $1.84(\mathrm{dt}, 2 \mathrm{H}, \mathrm{J}=6.4$ and $\mathrm{J}=15.2 \mathrm{~Hz})$ are in agreement with the saturated side chain. In the ${ }^{13} \mathrm{C}$ NMR spectrum, the three $\mathrm{CH}_{2}$ signals at $62.1 ; 34.4$ and 31.7 ppm were to assigned at C-3', C-1' and C-2' respectively and the signal at $\mathrm{d}=62.1 \mathrm{ppm}$ confirms the presence of primary carbinolic carbon. The structure of compound $\mathbf{6}$ differs mainly from that of $\mathbf{5}$ in the side chain signals because in the ${ }^{1} \mathrm{H}$ NMR spectrum signal at $\mathrm{d}=3.96$ $(\mathrm{m}, 1 \mathrm{H})$ and $1.23(\mathrm{~d}, 3 \mathrm{H}, \mathrm{J}=6.2 \mathrm{~Hz})$ were observed, indicating the presence of secondary alcohol.

In the ${ }^{1} \mathrm{H}$ NMR spectrum of compound 7 , three signals at $\mathrm{d}=3.71(\mathrm{t}, 2 \mathrm{H}$, $\mathrm{J}=6.2 \mathrm{~Hz}) ; 2.96(\mathrm{dd}, 2 \mathrm{H}, \mathrm{J}=6.4$ and $\mathrm{J}=8.6 \mathrm{~Hz})$ and $1.90(\mathrm{~m}, 2 \mathrm{H})$ were assigned to the saturated side chain $\mathrm{H}-3^{\prime}, \mathrm{H}-1^{\prime}$ and $\mathrm{H}-2^{\prime}$, respectively. On the other hand, the MS spectrum from the acetate $\mathbf{1 0}$ presented a molpeak at m/z 163 $\left[\mathrm{M}^{+}\right]$(19.9) was observed.

In the ${ }^{1} \mathrm{H}$ NMR spectrum of isomer 8 , the presence of signal at $\mathrm{d}=4.11 \mathrm{ppm}$ $\left(\mathrm{m}, 1 \mathrm{H}^{\prime}\right)$ was to assigned at carbinolic hydrogen in C-2' position (secondary alcohol). In addition the signal at $\mathrm{d}=1.31(\mathrm{~d}, 3 \mathrm{H}, \mathrm{J}=6.2 \mathrm{~Hz})$ was to assigned an terminal methyl group.

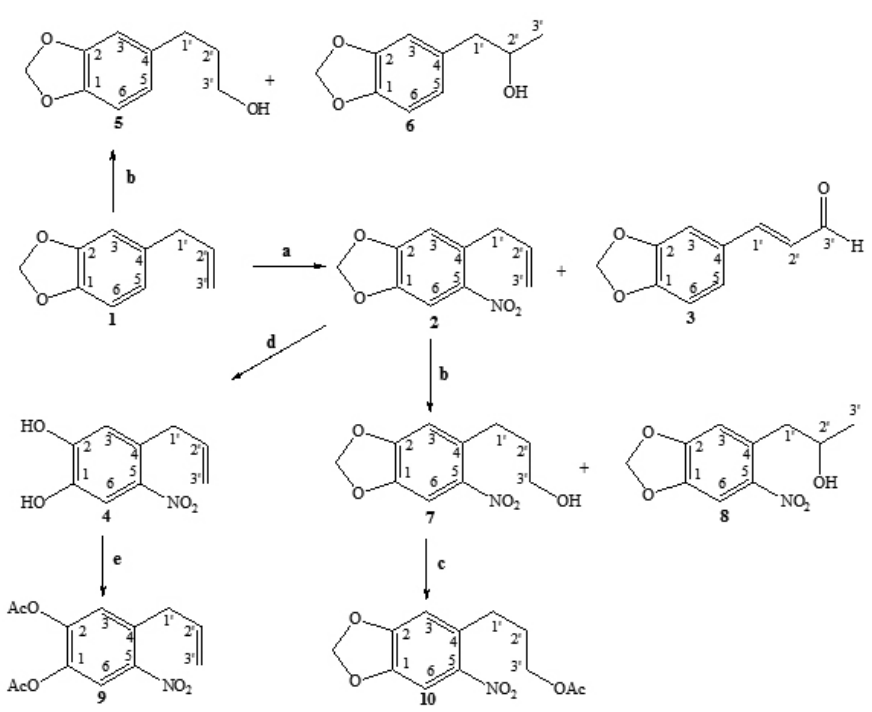

Scheme 1. Conditions: a. $\mathrm{HNO}_{3} / \mathrm{H}_{2} \mathrm{SO}_{4}(10: 1), \mathrm{HAc}$ (glacial), $-10^{\circ} \mathrm{C}, 4 \mathrm{~h}$, 2; $75.0 \%$ and $35.2 \%$. b. i) $\mathrm{BH}^{-} \mathrm{DMS}^{2}$, THF, $(2 \mathrm{M}) ; \mathrm{N}_{2},-10^{\circ} \mathrm{C}, 15 \mathrm{~min}$, and r.t, $1 \mathrm{~h}$; ii) $\mathrm{NaBO}_{3} \cdot 4 \mathrm{H}_{2} \mathrm{O} / \mathrm{H}_{2} \mathrm{O}$, r.t, $2 \mathrm{~h} ; \mathbf{5} ; 59.4 \% ; \mathbf{6} ; 1.1 \% ; 7 ; 53.1 \%$ and $\mathbf{8} ; 2.4 \%$. c. Ac, O, DMAP, $\mathrm{CH}_{2} \mathrm{Cl}_{2}$, 2h, r.t; 10; $95.1 \%$. d. i) $\mathrm{AlCl}_{3} / \mathrm{CH}_{2} \mathrm{Cl}_{2} ; \mathrm{N}_{2},-10^{\circ} \mathrm{C}, 2 \mathrm{~h}$ ii) $\mathrm{H}_{2} \mathrm{O}$, r.t, 18 h; $4 ; 57.4 \%$. e. $\mathrm{Ac}_{2} \mathrm{O}$, DMAP, $\mathrm{CH}_{2} \mathrm{Cl}_{2}$, 2h, r.t.; $9 ; 94.3 \%$.

\section{Biological Results}

The in vitro cytotoxic evaluation of safrole $\mathbf{1}$ and the compounds 2-8 (see Scheme 1) indicate that the cell viability expressed as $\% v s$. control vehicle (ethanol $1 \%$ ) for the compounds 3 and $\mathbf{4}$ was dose-dependant (mM). The $\mathrm{IC}_{50}$ values of compounds $\mathbf{3}, \mathbf{4}$, safrole and the reference compound daunorubicin are summarized in Table 1 as the micromolar concentration that produces $50 \%$ cell growth inhibition after 72 hours of drug exposure. The results indicate that derivatives 3 and $\mathbf{4}$ are more toxic than safrole against MCF-7 cells and that compound 4 , present higher toxicity against all the cancer cells tested than the parent compound and the derivative 3 . The activity of compounds $2,5,6,7$ and $\mathbf{8}$ was comparable to that of safrole (data not shown). However, daunorubicin is at least one hundred times more active as anticancer compound against MDAMD231 cells and 300-500 times more effective towards MCF-7 cells than the safrole derivatives $\mathbf{3}$ and $\mathbf{4}$. Nevertheless, it is important to emphasize that compound $\mathbf{4}$ has 10 times less cytotoxicity than daunorubicin against normal cells, an interesting characteristic.

Table 1. Cytotoxic activity of synthesized derivatives safrole compounds against two breast cancer cell lines, MCF-7, MDA-MB231, one colon cancer cell line, DLD-1 and a dermal human fibroblast cells, DHF, expressed as inhibitory concentration $\mathrm{IC}_{50}$

\begin{tabular}{|c|c|c|c|c|}
\hline \multirow{2}{*}{ Compounds } & \multicolumn{3}{|c|}{$\mathbf{I C}_{50}(\boldsymbol{\mu M})$} & \\
\cline { 2 - 5 } & $\mathbf{M C F - 7}$ & $\begin{array}{c}\text { MDA- } \\
\text { MB231 }\end{array}$ & DLD-1 & DHF \\
\hline 3 & $80 \pm 6.92$ & $>100$ & $>100$ & $>100$ \\
\hline 4 & $55.0 \pm 7,11$ & $37.5 \pm 2.65$ & $44.0 \pm 6.92$ & $>100$ \\
\hline Daunorubicin & $0.16 \pm 0.02$ & $0.35 \pm 0.04$ & $0.24 \pm 0.03$ & $12.3 \pm 1.81$ \\
\hline Safrole & $>100$ & $>100$ & $>100$ & $>100$ \\
\hline
\end{tabular}

Safrole has been shown to become cytotoxic to various human cell types at higher concentrations $(5-10 \mathrm{mM})^{19,20}$. In the other hand our data showed that the cytotoxic activity of $\mathbf{3}$ and $\mathbf{4}$, is reached at micromolar concentrations, what indicates that this derivatives proved to be more toxic than safrole itself against the selected cancer cells.

\section{CONCLUSION}

In synthetic terms, the classic nitration method used for the synthesis of compound $\mathbf{2}$ led to better yields than those previously reported in literature. An increase in the yields of primary alcohols with lower amounts of the secondary alcohol was achieved preparing the organoborane complex at $-10^{\circ} \mathrm{C}$, omitting the use of solvents and an alkaline environment external to the oxidation process 
carried out by the sodium per borate in water. The formation of catechols from safrol with $\mathrm{AlCl}_{3}$ was favoured by the presence in the molecule of the electron attractor group $\left(\mathrm{NO}_{2}\right)$. The safrole derivatives $\mathbf{3}$ and $\mathbf{4}$ proved to be more toxic than safrole itself against the selected cancer cells.

\section{ACKNOWLEDGEMENTS}

The authors thank Universidad de Valparaiso (grant DIPUV 27/2006), Universidad Técnica Federico Santa María (grant DGIP $\mathrm{N}^{\circ} 13.08 .59, \mathrm{~N}^{\circ}$ 13.09.42 and PIIC 2009) and Universidad Andrés Bello (grant DI-18-08/R) for financial support.

\section{REFERENCES}

1.- Chen, G. L.; Yang, L.; Rowe, T. C.; Halligan, B. D.; Tewey, K.; Liu; L.; J. Biol. Chem., 259, 13560, (1984).

2.- Capilla, A. S.; Sanchez, I.; Caignard, D. H.; Renard, P.; Pujol, M. D.; Eur. J. Med. Chem., 36, 389, (2001).

3.- Hidalgo, M.E.; Carrasco, H.; Espinoza, L; De la Rosa, C.; Cardona, W.; Gallardo, C.; Quim. Nova., 32, 1467, (2009).

4.- Carrasco, H.; Espinoza, L.; Cardile, V; Gallardo, C.; Cardona, W. Lombardo, L.; Catalán, K.; Cuellar, M. and Russo, A.; J. Braz. Chem. Soc., 19, 543, (2008).

5.- Skehan P, Storeng R, Scudiero D, Monks A, McMahon J, Vistica D, Warren JT, Bokesch H, Kenney S, Boyd MR; J. Nat. Cancer Inst., 82, 1107, (1990).

6.- Vichai, V. and K. Kirtikara; Nature Protocols, 1, 1112, (2006).
7.- Da Rosa, F., Revelo, R., Nascimento, M.; J. Braz. Chem. Soc., 14, 11, (2003).

8.- Khadem, S., Joseph, R., Rategar, M., Leek, D.M., Outdatchin, K.A., Arya, P.; J. Comb. Chem., 6, 724, (2004).

9.- Leite, A.C, Peixoto, K., De Souza, I., De Araujo, J.M., Brondani, D.J.; Eu. J. Med. Chem., 39, 1059, (2004).

10.- Nascente, L., Ceripes, V., Romeiro, L.; Sociedade Brasileira de Química, $29^{\mathrm{a}}$ Reunion Anual SBQ, 2005.

11.- Kabalka, G.W., Shoup, T.M. and Goudgaon, N.M.; J. Org. Chem., 54, 5930, (1989).

12.- Lange, R. G., J. Org. Chem., 27, 2037, (1962).

13.- Avery, M. A., Verlander, M. S. and Goodman M., J. Org. Chem., 45, 2750, (1980).

14.- De Amorim, M., Da Silva, A. J. M. and. Costa, P. R. R; J. Braz. Chem. Soc., 12, 346, (2001).

15.- Costa, P.R.R.; Quím. Nova, 23, 357, (2000).

16.- Backes, M., Von der Fakultät für Mathematik, Informatik und Naturwissenschaften der Rheinisch-Westfälischen Technischen Hochschule Aachen zur Erlangung des akademischen Grades eines Doktors der Naturwissenschaften, mai, 2004.

17.- Cox, M., Klass, G.; F. Sci. Inter., 164, 138, (2006).

18.- Barreiro, E. J., Fraga, C.A.M.; Quím. Nova, 22, 744, (1999).

19.- Hung, S. L.; Chen, Y. L.; J. Periodontal Res., 38, 130, (2003).

20.- M., Uhl, C., Helma, S., Knasmuller; Mutat. Res., 468, 213, (2000). 